\title{
Reinforced soil bund as passive protection structures: the New Zealand experience
}

\author{
E Ewe Geofabrics New Zealand Ltd, New Zealand
}

\begin{abstract}
Reinforced soil structures are well known for their excellent performance in resisting external loads such as seismic shaking. The superior performance over rigid structures is due to the very ductile behaviour of the structures as a result of relatively closely spaced soil reinforcement inclusions in soil. The ductility of these structures is utilised in the field of very high dynamic impact energy of rockfall with an aim to protect infrastructure. Back-to-back reinforced soil structures or bunds are constructed with layers of reinforcement and suitable facing units designed to resist dynamic impact energy. Full-scale impact trials have been carried out on these structures in Italy and simplified design charts have been developed from there. Several of these reinforced soil bunds have been designed and constructed in Christchurch following the 2011-12 earthquake and in Kaikoura after the 2016 earthquake. This paper details case studies of two of these structures across Christchurch and Kaikoura in the south island of New Zealand.
\end{abstract}

Keywords: reinforced soil structures, at source control, passive protection structures, rockfall protection, hazard mitigation

\section{Introduction}

Two major earthquakes struck the south island of New Zealand five years apart. These earthquakes caused numerous rockfalls and mass land movements in the mountainous areas of the regions with hundreds of boulders and a large volume of landslide debris being deposited on residential areas, destroying houses and inundating the transport corridors.

In both earthquake events, the New Zealand government responded by setting up alliances of major contractors, consulting engineers, local council, and road and rail agencies to help with the restoration works. In both cases, the alliances were tasked with removal of the fallen rocks or debris, identifying the threats and the design of measures to mitigate the risk to an acceptable level.

The scale and complexity of the damage due to rockfalls and land mass movements were unprecedented. The 'at source control' approach, which is the common practice to mitigate rockfall protection hazards, is deemed inadequate and/or cost prohibitive for the majority of the site locations. The typical at source control methods include meshing over the source area, scaling or blasting to remove the rock sources, anchors or nailing to improve the stability of the slope, and modifying the geometry of the slope with benching among others.

The rock source areas are either not accessible, too large an area to treat with either of the above methods, the associated risks are too high for treatments such as benching or some residual risks remain even after extensive at source control and treatment. In situations such as this, there is a need to construct passive protection structures at convenient locations along the preferential path of the rockfall to protect the infrastructures located downhill.

\section{Passive protection structures}

Passive protection structures are engineered structures constructed at locations some distance away from the source of the falling rocks or shallow landslide mass. They are not intended to prevent rockfall or shallow landslides from occurring, nor are they intended to stabilise the slope surface, but instead to mitigate the 
damage by dissipating the energy of the rock/debris flow (Ministry of Business, Innovation \& Employment (MBIE) 2016). There are many types of passive protection structures, including:

- ETAG27 (European Organisation for Technical Approvals 2013) energy certified dynamic fences.

- Hybrid or attenuator fences.

- Reinforced soil bund or embankment.

- Catch ditches.

- Rock shed.

Recognising the need for more consistent and reliable engineering design of these structures, the New Zealand MBIE published the guidance document in November 2016 for the design of passive protection structures with a focus on rockfall risks. The document provides technical guidance for the design of passive protection structures based on current practice in Europe and North America (MBIE 2016). This paper focuses on the applications of reinforced soil bunds as the passive protection structure, while not discounting the effectiveness of the other structures. Each structure has its merits and shortcomings, and the choices depend on a number of considerations, including:

- Availability of space.

- Morphology of slopes.

- Scale of the problem.

- Initial cost/whole of life cost.

- Practicality of installation.

- Maintenance.

- Frequency of occurrence.

- Impact kinetic energy.

It is common that a combination of approaches are used on complex large-scale sites that may involve multiple 'at source control' options and passive protection structures. Two project case studies have been selected to be discussed.

\section{$3 \quad$ Reinforced soil overview}

Reinforced soils are structures with the inclusion of multiple horizontal layers of planar soil reinforcement. The application of soil reinforcement in retaining walls and slopes is well accepted internationally having over 40 years of use. Soil structures with steepened face angles of up to vertical are possible with soil reinforcement which otherwise would require a large soil fill volume and a natural fill slope. The reliability of modern soil reinforcement products means that engineers are now confident in designing these structures. Improvement in the polymer technology and manufacturing process also ensures that the soil reinforcement products are consistent in quality and performance. International codes of practice are now well established on the design of these structures.

The inclusion of reinforcement enhances the shear strength and stiffness of the reinforced soil structure. Soil particles are restrained from movement either due to confinement within the reinforcement apertures or simply by surface friction at the top and bottom of the reinforcement.

From here, a composite soil mass with vastly improved characteristics can be formed due to enhanced soil stiffness and ductility. These improved soil properties have the ability to limit deformation due to dynamic impact, seismic shaking and greater resistance to external load, while maintaining internal stability under self-weight. This feature is important when the structure is subject to rockfall impact and earthquake 
shakings for example. Again, the improved ductile nature of the reinforced soil mass contributes to the absorption and attenuation of the external impacts and shakings.

\subsection{Components of reinforced soil structures}

Reinforced soil structures consist of three major components:

- Soil fill: This is the compacted structural soil from front facing to rear of reinforcement. The best and most commonly used fill is well graded granular soil, although some relaxation of fill type is possible for gentler faced angles and use of flexible facing elements. For application on rockfall protection bunds, more than likely the in situ soil from the slope failure can be utilised to minimise the removal volume as long as the maximum particle size can be limited to an acceptable size for the reinforcement element and that the plasticity index of the soil is less than 20 .

- Reinforcement element: Modern soil reinforcement can be manufactured from polymer geo-grids, double twist wire mesh, steel straps, polymer straps, etc. The most common form of reinforcement for reinforced soil bunds are polymer geo-grids and polymer galvanised coated double twist mesh steel wire.

- Facing element: These are front facial units of the structure and are there to protect the front soil from natural erosion and weathering. The front face element therefore needs to be a durable system under natural weather exposure that will stand the test of time. They are commonly made from concrete blocks, concrete panels, double twist steel mesh, gabion, etc. The common facial unit for rockfall protection application is the flexible type with double twist wire mesh. The characteristic of the double twist mesh ensures that it can be replaced by local patching with a similar mesh with minor impact depth from rocks due to withstanding unravelling.

Each component is essential to ensure the structure performs according to the design requirements for both ultimate and serviceability limit state. Another aspect that is not part of the reinforced soil, but essential, are the drainage considerations. This includes the internal drainage at the rear of the reinforcement or immediately behind the facing element and external drainage to cater for surface water during and upon completion of structure.

\section{$4 \quad$ Reinforced soil rockfall protection bund}

There are many types of bunds or embankment utilised for rockfall protection. They were originally constructed from compacted unreinforced natural soil and were designed for rather low impact energy or boulder velocity (Lambert \& Bourrier 2013). The natural unreinforced slope angle on the up-slope side also meant that there is a greater chance of boulders escaping the bunds with high velocity. Quite often, the large footprint required for the natural unreinforced soil slope also means that they may not be applicable most of the time due to space constraints. From here, various forms of protection structures have been built to achieve a steeper face angle. These include mass gravity gabions, large rocks, concrete walls, and timber/concrete cribs. The reinforced soil structures are still the most cost-effective and technically reliable form of protection structures to date. This is due to the number of researches conducted on them from physical impact trials and computer finite element method (FEM) modelling, as well as validation from actual rockfall events. Simplified design charts have been developed for reinforced soil bunds following the research to allow engineers to design the bund's ability to absorb impact energy, estimation of the impact depth on the up-slope side, and minimum height requirement (Grimod \& Giacchetti 2011; Ronco et al. 2009).

It has been reported that a reinforced soil bund can be more economical to construct than a dynamic catch fence for energies greater than approximately 3,000 kJ (Brunet et al. 2009). However, this may not be the sole consideration for the adoption of reinforced soil bund over other types of passive protection structures. Many examples in New Zealand indicate the adoption of reinforced soil bund with lower than 3,000 kJ energies despite higher initial installation cost. This is because reinforced soil bunds can withstand multiple impacts without having to be replaced. As long as the impacts are within the serviceability limit or are low 
energy impacts, very low to no maintenance is requirement and a longer life expectancy is possible. These are among other factors for the popularity of bunds over other solutions.

\subsection{The full-scale trial}

The Polytechnic University of Turin conducted a full-scale impact test on the reinforced soil bund with steel mesh facing during 2001-2003. The test involved a hauling device that is able to launch reinforced concrete blocks of up to $8,700 \mathrm{~kg}$ with a speed of $31 \mathrm{~m} / \mathrm{s}$ against the bund reinforced with polymer geo-grid (Peila 2013). Please see Figure 1 for the test arrangement.

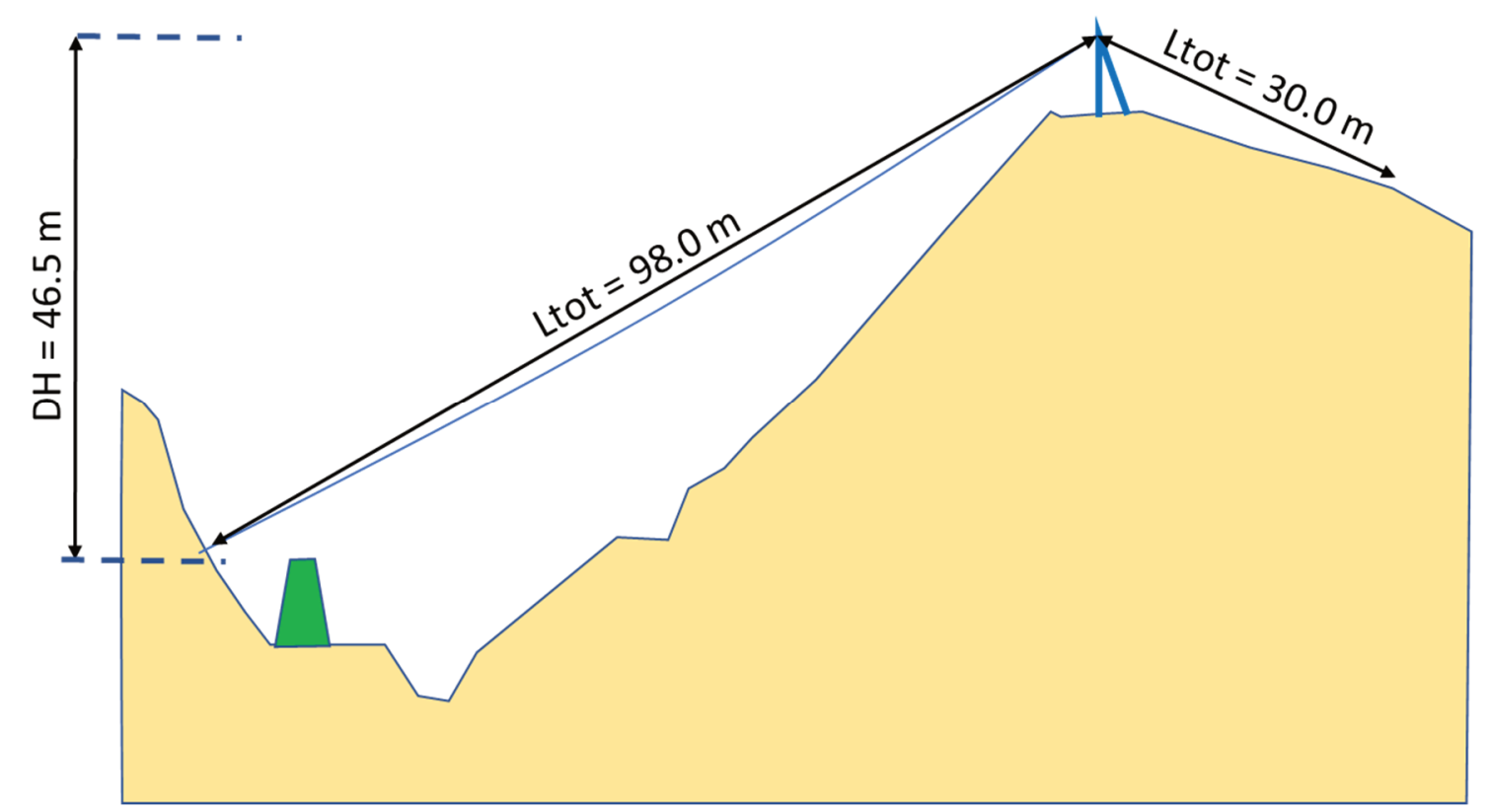

Figure 1 Test arrangement for the reinforced soil bund by the Polytechnic University of Turin (Peila 2013)

There were four tests conducted on the bund. Three were reinforced with geo-grid at $600 \mathrm{~mm}$ spacing and one without geo-grid reinforcement. The four tests are summarised in Table 1 . Figures $2 a$ and $2 b$ show the geometry of the soil bunds.

Table 1 Impact tests carried out on the bunds by the Polytechnic University of Turin (Peila 2013)

\begin{tabular}{lllllll}
\hline Test & $\begin{array}{l}\text { Block } \\
\text { mass (kg) }\end{array}$ & $\begin{array}{l}\text { Energy at } \\
\text { impact (kJ) }\end{array}$ & $\begin{array}{l}\text { Number of } \\
\text { impacts }\end{array}$ & $\begin{array}{l}\text { Geo-grid } \\
\text { reinforcement }\end{array}$ & $\begin{array}{l}\text { Soil } \\
\text { type }\end{array}$ & $\begin{array}{l}\text { Bund } \\
\text { geometry }\end{array}$ \\
\hline 1 & 5,000 & 2,400 & 1 & Yes & 1 & $\mathrm{~A}$ \\
2 & 8,700 & 4,180 & 3 & Yes & 1 & $\mathrm{~A}$ \\
3 & 8,700 & 4,180 & 1 & No & 1 & $\mathrm{~A}$ \\
4 & 8,700 & 4,180 & 1 & Yes & 2 & B \\
\hline
\end{tabular}

- Soil type 1 - sandy gravel.

- Soil type 2 - silty clay. 


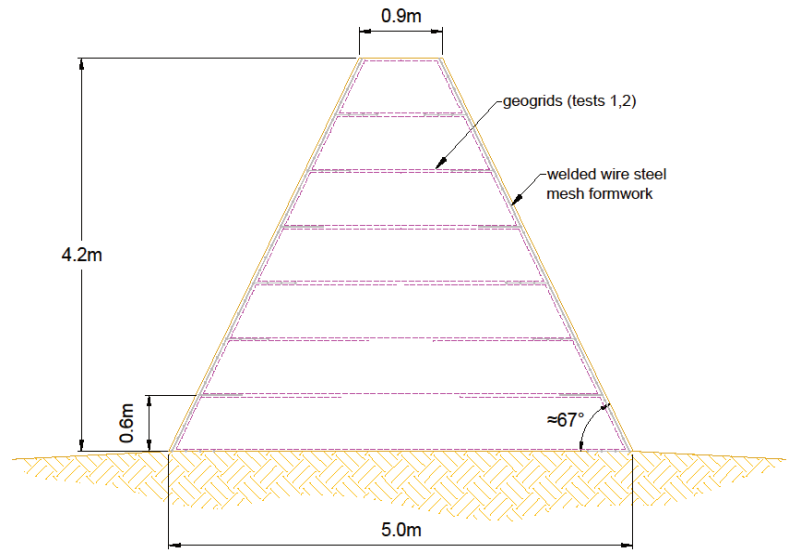

(a)

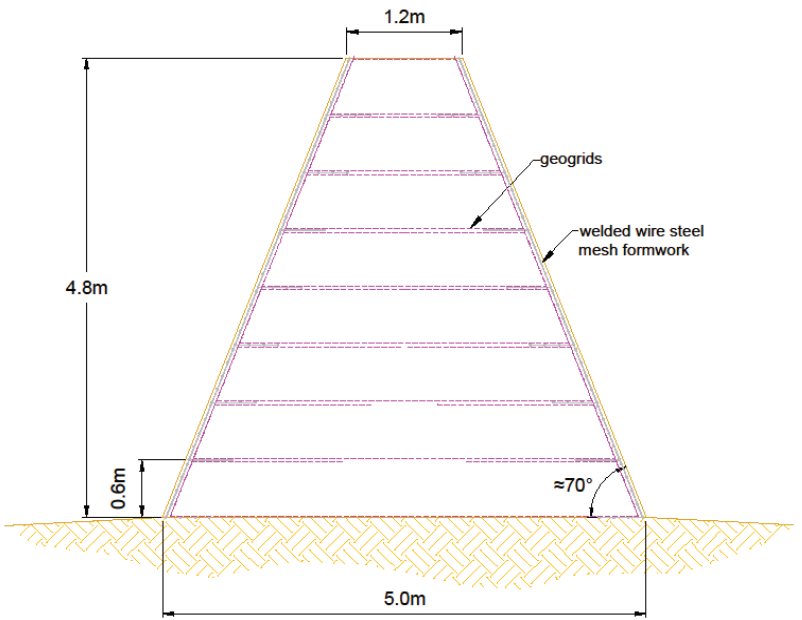

(b)

Figure 2 Bund geometry during the test. (a) Bund geometry A (test 1, 2 and 3); (b) Bund geometry B (test 4) (Peila 2013)

From here, the relationship between penetration depths on the up-slope side, boulder sizes and their kinetic energy can be derived. The visual comparisons of failure mode of the reinforced (test 2) and unreinforced (test 3) soil bund constructed with similar geometry due to very high impact energies can be shown in Figures $3 \mathrm{a}$ and $3 \mathrm{~b}$. These two bunds were constructed with a very thin crest width of $0.9 \mathrm{~m}$ for the tests, and the reason to see how the bund performed under the ultimate limit case and their mode of failure during very high impact.

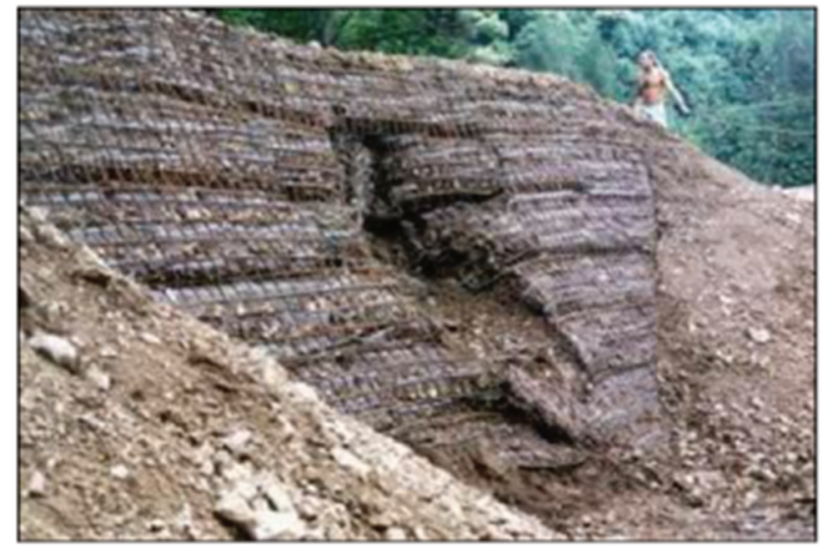

(a) Test 2 after the reinforced soil bund was impacted at an energy of 4,180 kJ. The bund deformed considerably locally without collapsing but reached its ultimate limit capacity. Nevertheless, the tests continued for another two impacts subsequently for this bund without repair. It was the third impact at the same location that caused the bund to collapse

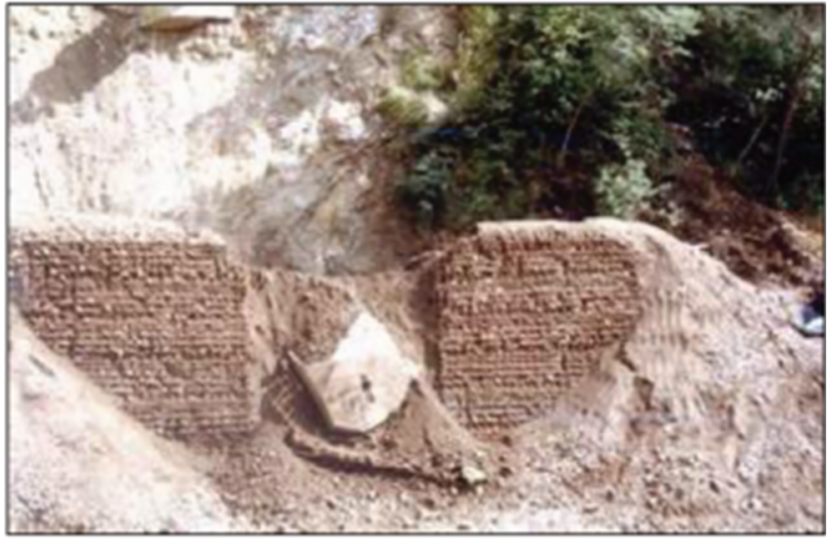

(b) Test 3 where the unreinforced bund with the same geometry collapsed completely under the same impact energy of $4,180 \mathrm{~kJ}$

Figure 3 Visual impact comparisons between the reinforced and unreinforced soil bunds. (a) Test 2; (b) Test 3 (Peila 2013)

Test 4, the reinforced soil bund was constructed $0.6 \mathrm{~m}$ taller at $4.8 \mathrm{~m}$ with a wider crest width and base footprint. The bund performed much better than test 2 with the same kinetic energy impact with the block absorbed into the reinforced soil bund and only minor deformation at the down-slope side. Figures 4a and $4 b$ show the visual comparison on side view and view from the impact side. 


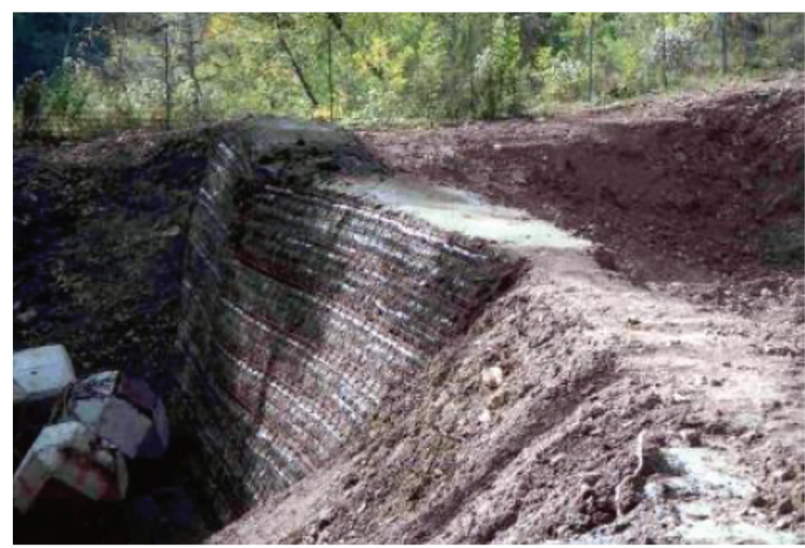

(a) Test 4 of the reinforced soil bund with wider crest width and height. Very minor down-slope side deformation

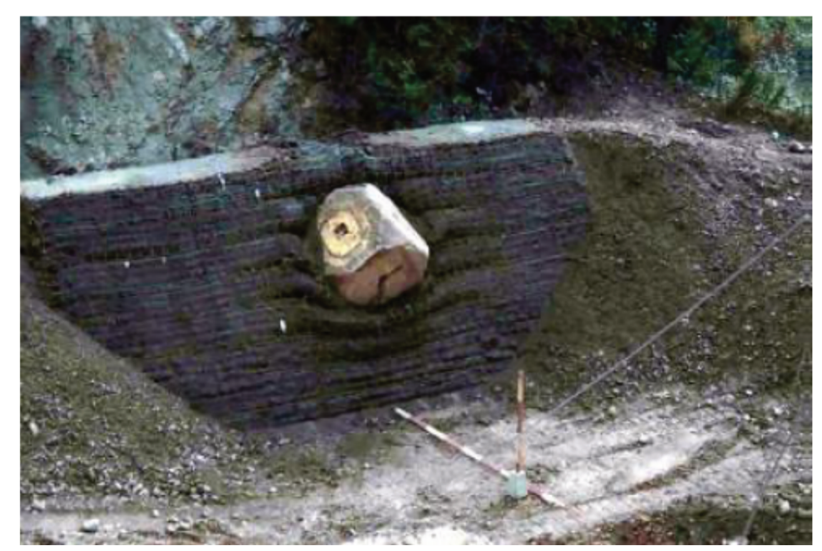

(b) Test 4 of the reinforced soil bund with wider crest width and height. Absorption of block into the reinforced soil bund creating a crater

Figure 4 Test 4 with wider crest width and taller reinforced soil bund. (a) View from the side; (b) View from impact side (Peila 2013)

Some of the key findings on the bund performance from these high-energy impact trials are the importance of having a mesh facing as well as layers of soil reinforcement with the bund. The tests validated the behaviour of the reinforced soil structure with ductility to absorb dynamic impact. Another essential aspect from the trial is the minimum height (i.e. the geometry of the bund to prevent a collapse as thickness plays an essential role in absorbing the block energy).

The Polytechnic University of Turin have further carried out 3D FEM based on these test results and real case studies of impacted bunds to validate a simplified design procedure for sizing the geometry of the reinforced soil bund. (Grimod \& Giacchetti 2011; Ronco et al. 2009). It is, however, not the focus of this paper to elaborate on the design.

\section{Sumner Road, Wakefield Avenue, Christchurch rockfall protection bund (Ewe 2016)}

During the 2010/11 Canterbury earthquake sequence, the Sumner area experienced rockfall, cliff collapse and landslides. Wakefield Avenue in Sumner is part of an important transportation link from Lyttelton (the port of Christchurch) to Sumner and Christchurch. There are four major sections along the route where it is necessary to mitigate the rockfall risks to an acceptable level for road users. Wakefield Avenue is one of these sections.

The primary objective of the Wakefield Avenue project is to mitigate rockfall risk posed by three rock source areas scattered some hundreds of metres above the road over a total affected length of $1.2 \mathrm{~km}$. Fallen blocks of up to $2.0 \mathrm{~m}$ nominal diameter have been observed at the site. Trajectory analysis and post-earthquake observations indicated that falling rocks have impacted the road and that there is a risk that they could reach the residential zone across the road. Initial attempts to mitigate the risk by scaling and removing the loose rocks on the slope were judged not to be feasible after subsequent earthquakes resulted in additional rockfall that caused further damage to the cliffs and rock bluff source areas. It was not considered practical to undertake scaling works over the large source area, nor was there any certainty that scaling would successfully treat the problem as it was unknown how far the damage extended into the rock mass. Mesh draping over the entire source area to control the rockfall was deemed to be cost prohibitive due to the large surface area for meshing. Rockfall analyses were performed by the engineers on various sections along Wakefield Avenue. The final decision was made to construct passive rockfall protection structures at three locations to intercept the falling rocks. The longest bund being $410 \mathrm{~m}$ long while the other bunds are 132 and $26 \mathrm{~m}$ in length. 
The rockfall analysis data was collated into three major categories based on the boulder sizes, bounce height and kinetic energy based on the design 95th percentile boulder size. The input data for the bund geometry determination is summarised in Table 2.

Table 2 Input data from trajectory analysis for reinforced soil bund geometry sizing

\begin{tabular}{|c|c|c|c|}
\hline & Bund 1(a) & Bund 1(b) & Bund 2 \\
\hline Boulder unit weight & $25 \mathrm{kN} / \mathrm{m}^{3}$ & $25 \mathrm{kN} / \mathrm{m}^{3}$ & $25 \mathrm{kN} / \mathrm{m}^{3}$ \\
\hline Nominal boulder diameter & $2.0 \mathrm{~m}$ & $2.0 \mathrm{~m}$ & $2.0 \mathrm{~m}$ \\
\hline Nominal boulder volume & $4.2 \mathrm{~m}^{3}$ & $4.2 \mathrm{~m}^{3}$ & $4.2 \mathrm{~m}^{3}$ \\
\hline $\begin{array}{l}\text { Bounce height at the proposed } \\
\text { embankment location, } h_{b} \text { (bottom) }\end{array}$ & $1.4 \mathrm{~m}$ & $3.8 \mathrm{~m}$ & $1.5 \mathrm{~m}$ \\
\hline $\begin{array}{l}\text { Bounce height at the centre of the } \\
\text { block, } h_{d} \text { (centre of mass) }\end{array}$ & $2.4 \mathrm{~m}$ & $4.8 \mathrm{~m}$ & $2.5 \mathrm{~m}$ \\
\hline Expected kinetic energy & $1,200 \mathrm{~kJ}$ & $900 \mathrm{~kJ}$ & $2,600 \mathrm{~kJ}$ \\
\hline
\end{tabular}

The results are Green Terramesh bunds with three different heights ranging from 3.6 to $6.0 \mathrm{~m}$ and face inclinations of $70^{\circ}$ or $80^{\circ}$. Along the different sections of the bund, choices of surface finish consist of rockfill face and vegetated face. Figures 5, 6 and 7 show various stages of the bund from construction to completion.

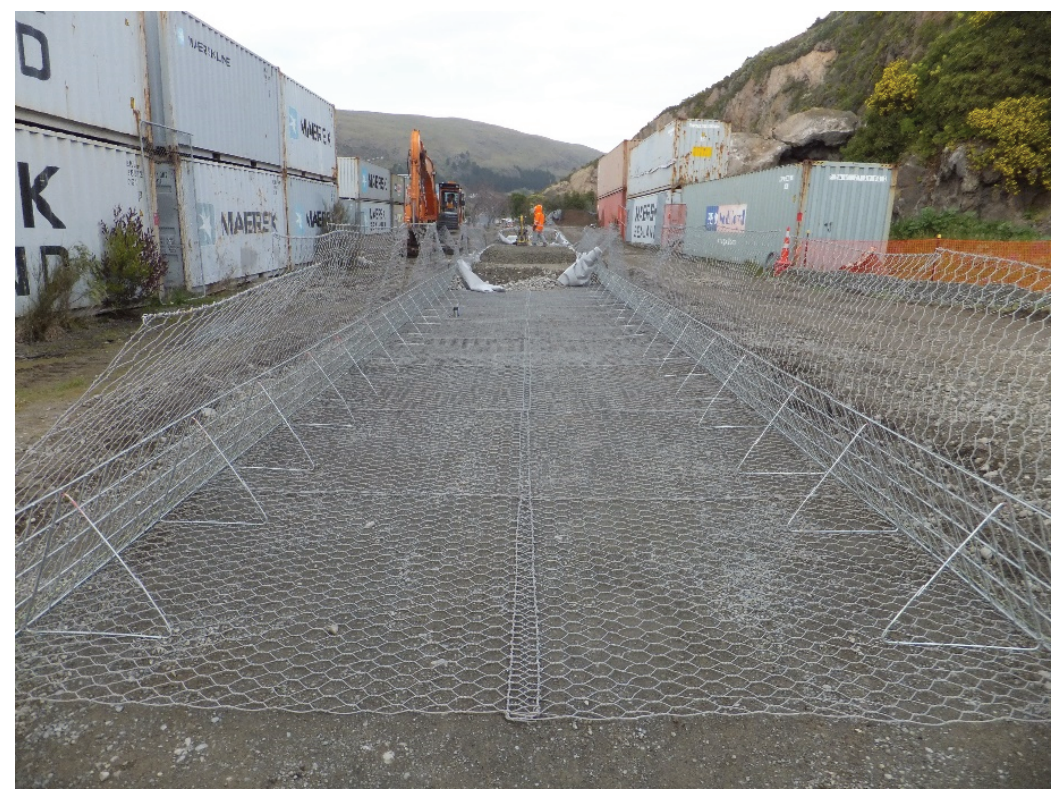

Figure 5 Cross-section view of the reinforcing facial unit before filling 


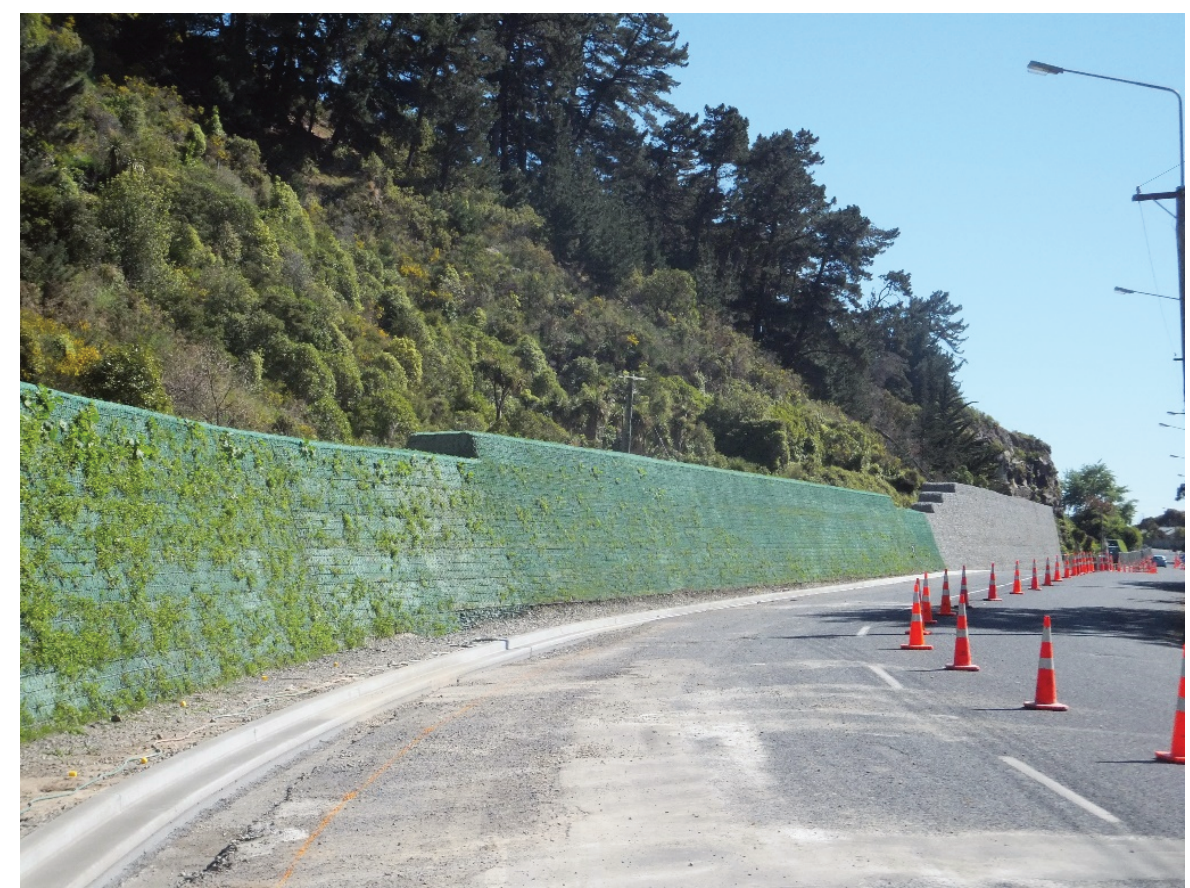

Figure 6 View of the reinforced soil bund with transition between vegetated and rockfill front face

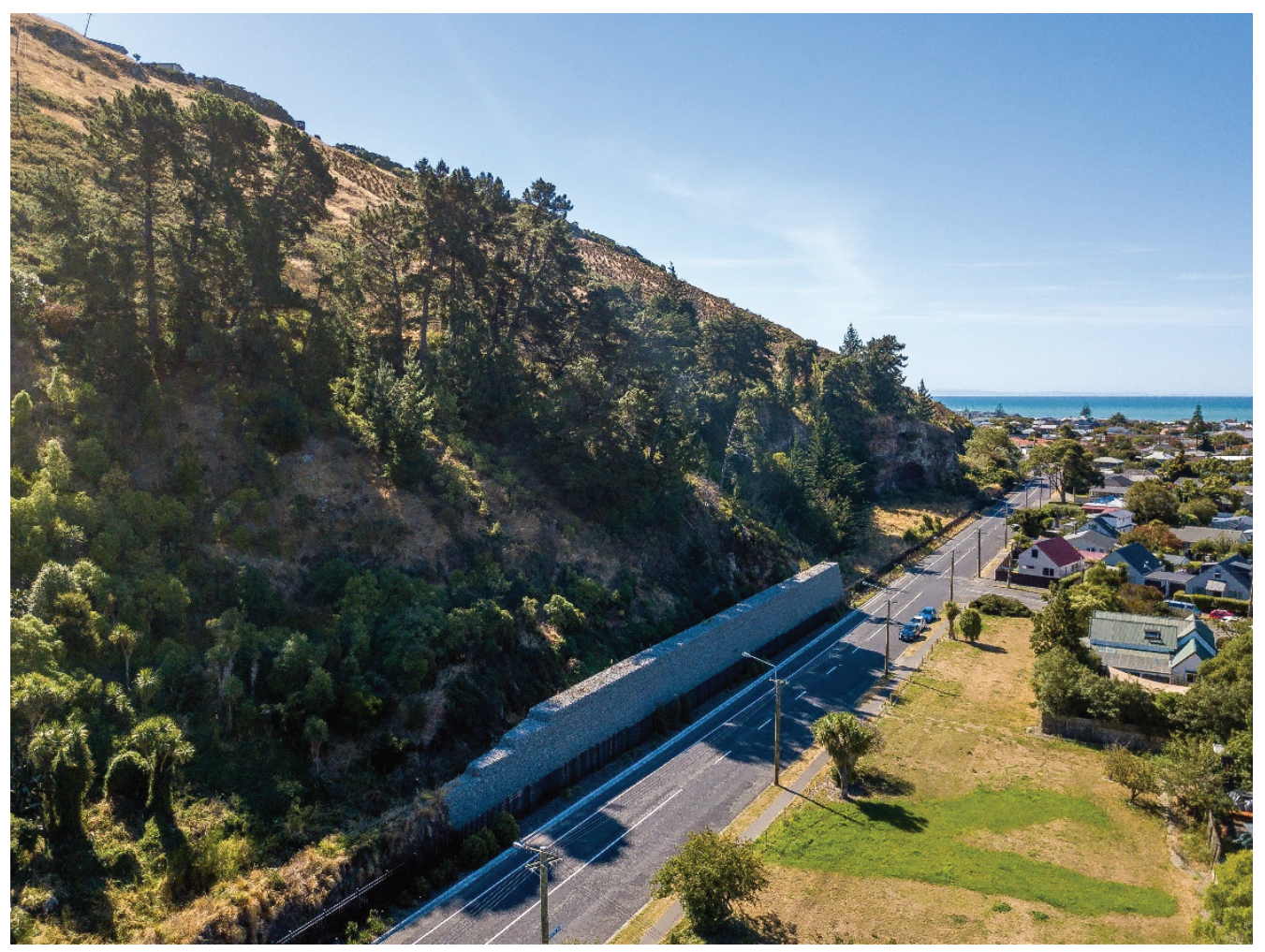

Figure 7 Bird's eye view of the completed reinforced soil bund

\section{Site P7 Kaikoura coastal road rockfall protection bund (Colgan \& Ewe 2019)}

Kaikoura is a coastal town in the North Canterbury region of the south island of New Zealand. It is a popular tourist destination known for its abundant wildlife and its sperm whale population. The region was badly affected by the November 2016 earthquake. The 7.8 magnitude earthquake caused landslides and rockfalls along the coastal state highway, SH1. SH1 connects Kaikoura, north to Blenheim and south to Christchurch, 
as well as being a major tourist route with its scenic views along the coast. The rail corridor also sits along $\mathrm{SH} 1$, responsible for carrying resources in from Picton.

Site P7 is located $1 \mathrm{~km}$ north of Ohau Point on the Kaikoura coast. Extensive landslide debris from the slopes above the transport corridor covered over the road and rail tracks at the toe after the earthquake. Figure 8 is a bird's eye view of the P7 site slip. After major removal of the debris, the potential for further release of loose rocks from the source area was considered to be unacceptable. Engineering works were required to mitigate this risk to an acceptable level.

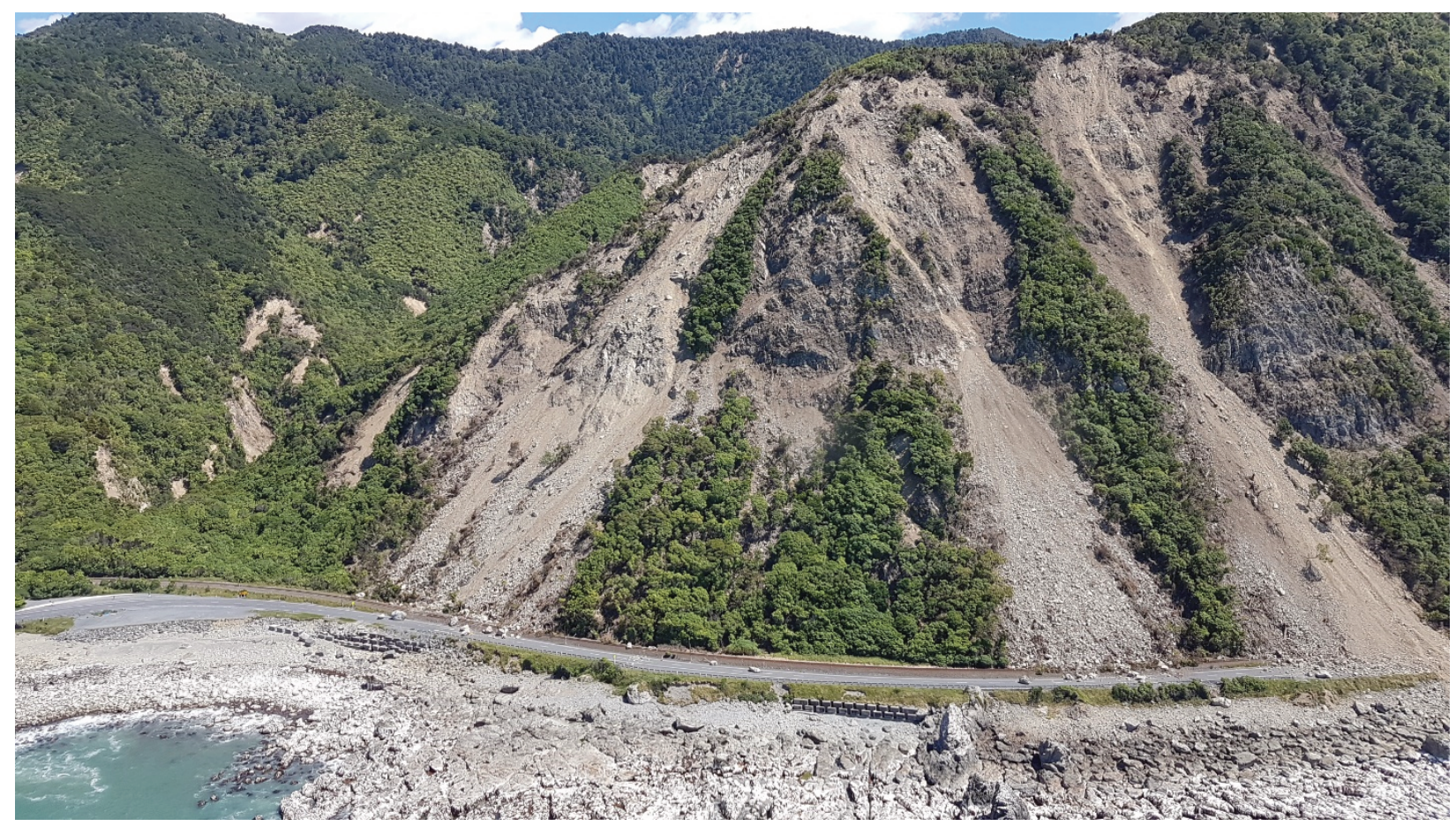

Figure 8 Site P7 slip on Kaikoura coastal road

With the source area spanning approximately $650 \mathrm{~m}$ long and $250 \mathrm{~m}$ above road level, at source control using meshing over the entire slope was ruled out. Nailing to stabilise the slope was also not an option due to the potential risk of surface material movement posing a danger to workers. Passive protection structure at the toe appeared to be the most favourable approach technically. Key considerations for the passive protection structures were:

- Small footprint to avoid encroaching into the rail and road transport corridor and allowing a catch ditch on the up-slope side for future maintenance.

- Low maintenance: multiple impacts are expected on this site.

- Durability: structure has to last the required design life in the aggressive coastal environment.

- Resilience of the structure dealing with over design-level impacts.

- Ease of repair.

- Low deflection distance after impact to prevent encroaching into the rail corridor.

- Use of site won material as the reinforced soil bund fill. 


\subsection{Passive protection structures considered}

Considering the site constraints and design requirements, the passive protection structures considered for the project site were as follows:

- ETAG27 certified dynamic fence: a rockfall catch fence could be an option for this site but was not in favour for a number of reasons:

- Design impact energy of up to $10,000 \mathrm{~kJ}$ at one location.

- Deflection distance requirement for the dynamic fence means no advantage on minimising encroachment.

- Higher maintenance cost due to the frequent rockfall occurrence.

- Less durable due to exposure of steel components to a coastal environment.

○ Less resilient when subjected to multiple rockfalls or shallow landslide impacts.

- Unreinforced natural soil bund: the shallow side slope angles of unreinforced soil bund means a large footprint is required and is therefore ruled out. The flatter slope angle is also a greater risk for rolling over the top from very high velocity rocks with rotational energies.

- Upslope catch benches: some excavated benches on the upslope were created during the initial clearing of debris following the earthquake on some parts of the site. However, extensive benching on the entire slope was not in favour due to difficulty in construction and future maintenance. Rockall modelling also indicated that benching alone is not adequate as a standalone approach to the rockfall risk at this site.

- Reinforced soil bund: the reinforced soil bund was selected for this site as the most favourable mitigation option. The choice was made because of the following considerations:

- Smaller foot print: the $70^{\circ}$ face angle of the reinforcing facial unit (Green Terramesh unit) with polymer geo-grid at taller height creates a much smaller footprint than a natural unreinforced slope.

- Low maintenance: the reinforced soil bund with rockfill facade with Green Terramesh facing unit requires zero maintenance.

- Greater resilience: the bund is proven to withstand multiple serviceability limit state (SLS) rockfall impacts and a single extreme event without collapsing.

- Durability: the polymer on top of Galmac ( $95 \% \mathrm{Zn} / 5 \% \mathrm{Al}$ ) coated steel wire of the Green Terramesh reinforcing unit ensures a $>50$ years life expectancy of exposure in the coastal environment.

The free-draining debris from the slip have been regraded and re-used as fill material within the reinforced soil bund, thereby minimising the carbon footprint. The external faces of the reinforcing unit are formed by laying clean rocks lined with geotextile in between the fill and rock face. Figure 9 shows side view of the reinforced soil bund in construction. Rock face fill was chosen for aesthetic appearance as well as minimising maintenance on likelihood of weeds growing on the front face. Side view of the bund close to completion is shown in Figure 10.

Further details of the design aspects of the reinforced soil bund have been reported in another paper (Colgan \& Ewe 2019). The final bund design was $488 \mathrm{~m}$ long in two parts including a $10 \mathrm{~m}$ gap to allow access for clearing debris. The southern section is $185 \mathrm{~m}$ with an exposed height of $5.4 \mathrm{~m}$ above the existing ground level, while the northern section is $293 \mathrm{~m}$ long and stands $3.6 \mathrm{~m}$ high; both bunds have a minimum crest width of $1.5 \mathrm{~m}$. Figure 11 shows a bird's eye view of the completion of the reinforced soil bund. 


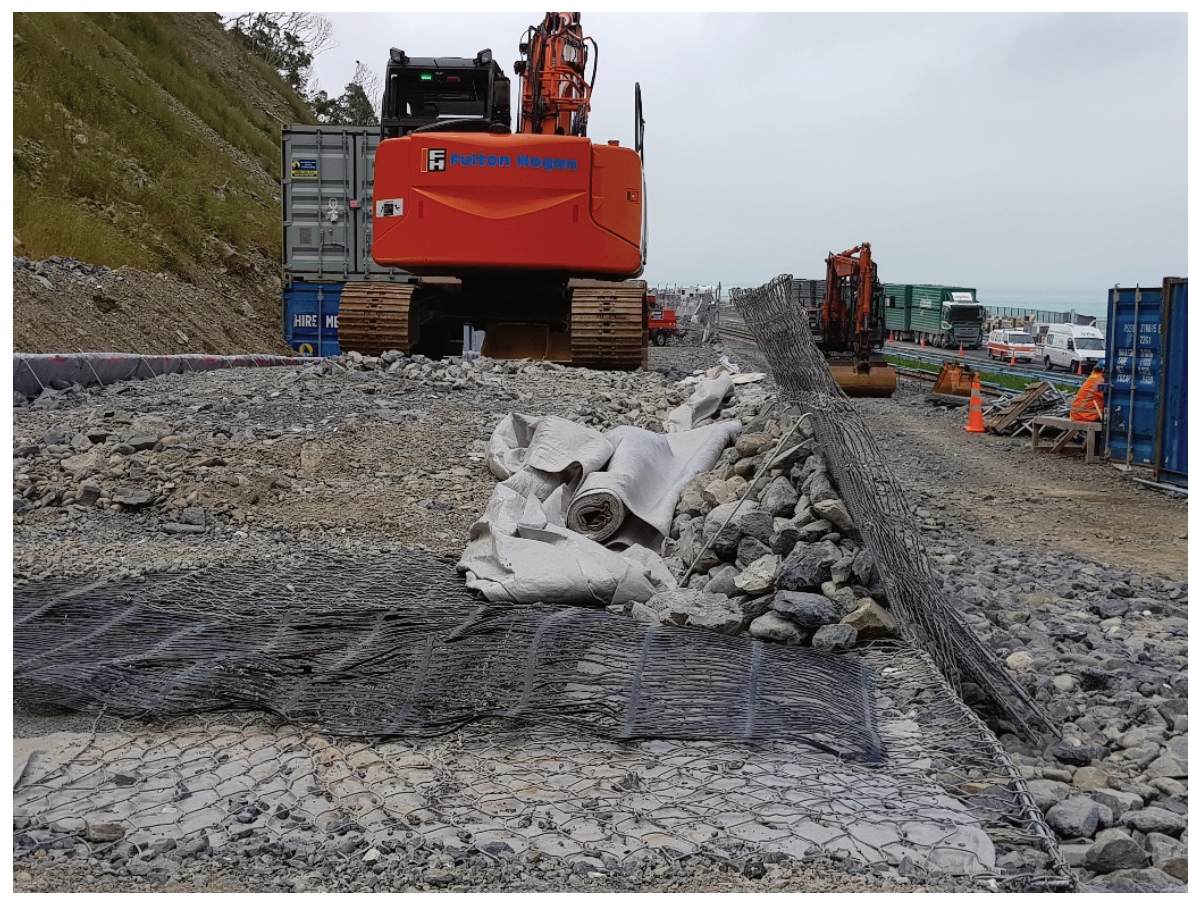

Figure 9 Construction of the reinforced soil bund with rockfill face

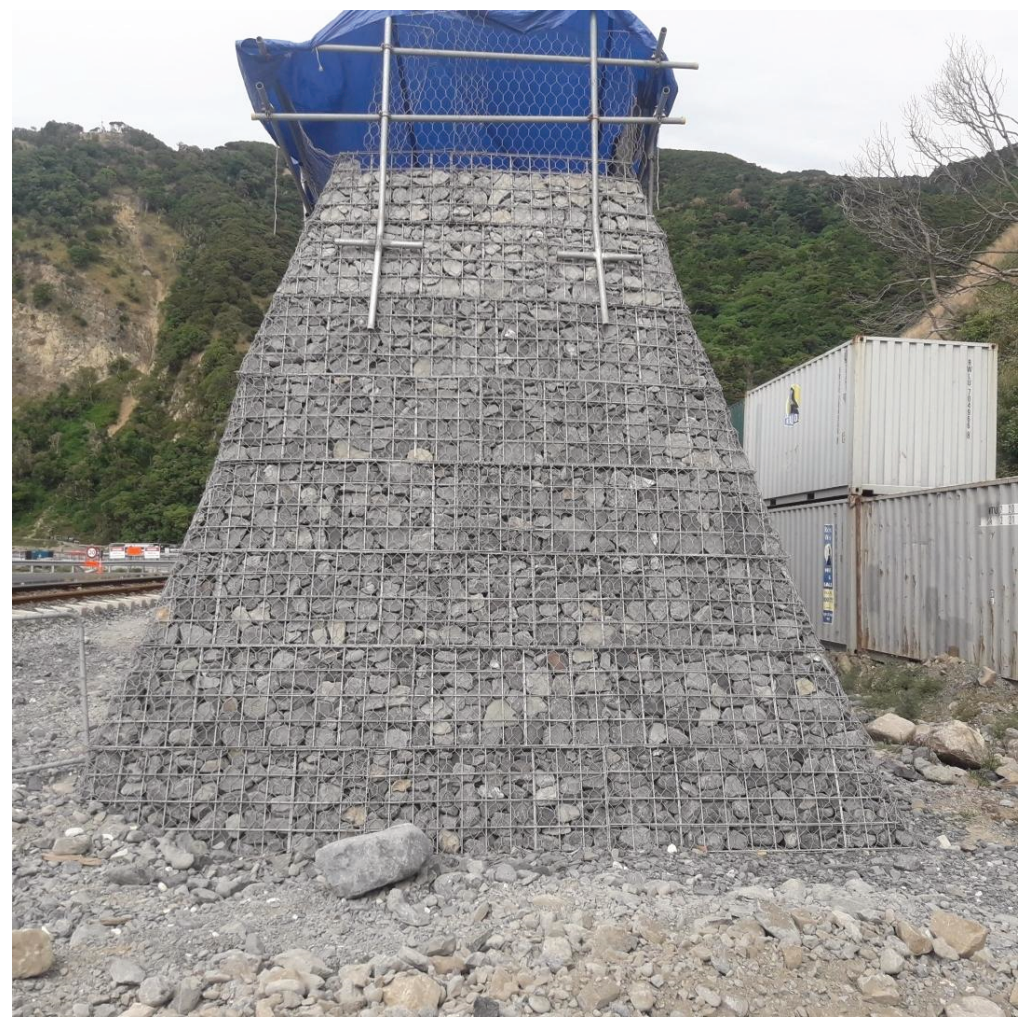

Figure 10 Side view of the reinforced soil bund with rockfill face 


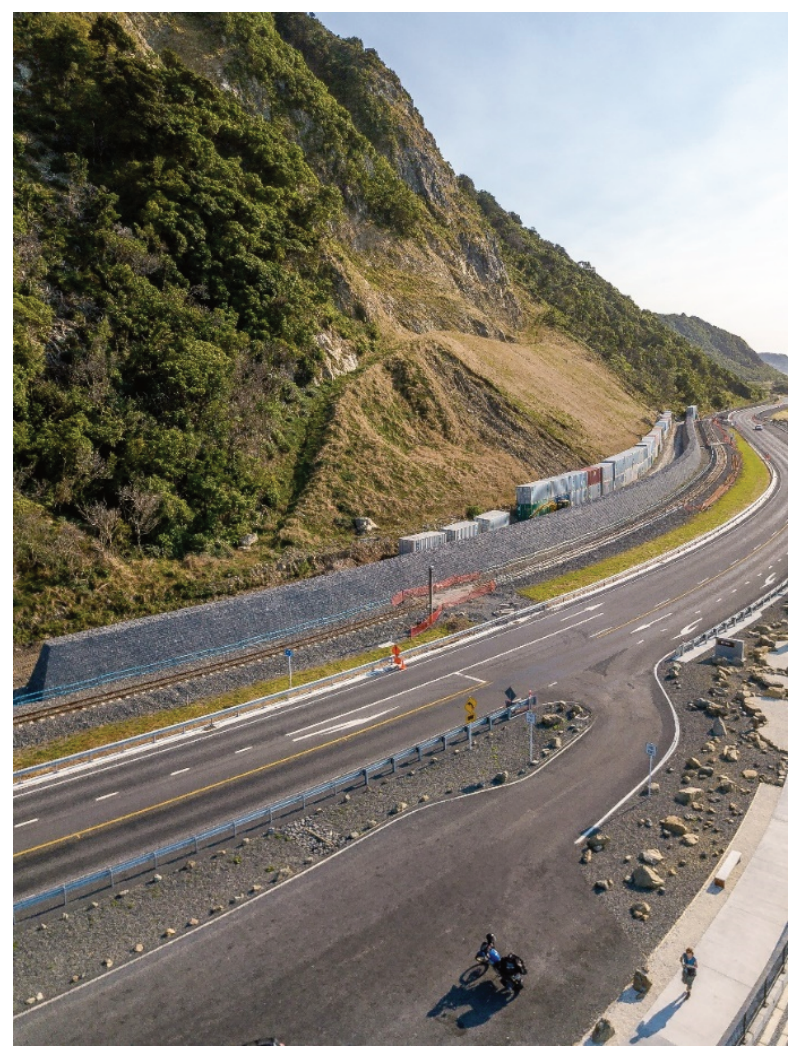

Figure 11 Bird's eye view of the completed reinforced soil bund (containers now removed)

\section{Conclusion}

The earthquake sequence in Christchurch and Kaikoura has created rockfall and shallow landslide problems that require remedial solutions different from conventional at source controls. Passive protection structures are one of the approaches that is a cost-effective and technically feasible strategy. With modern computer software for trajectory analysis and calibration onsite, rockfall hazards can be quantified to a high degree in terms of their expected kinetic energies and bounce heights, among other parameters.

Reinforced soil bunds or back-to-back reinforced soil structures have proven to be a highly effective option for areas with significant rockfall risks and complex or large-scale upslope catchment area. Full-scale impact tests and numerical modelling calibration have been carried out on these structures with simplified design methods available for engineers based on estimated penetration depth and minimum thickness requirement. New Zealand MBIE published the design guideline for rockfall protection works where reinforced soil bunds is one of the passive protection structures listed.

The critical benefits of reinforced soil bunds over other protection measures include the ability to receive multiple impacts, can be designed to a very high energy level of $>10,000 \mathrm{~kJ}$, and low level of maintenance in response to low energy impact when compared to fences which in turns reduces the whole of life cost significantly.

Two significant project case studies of reinforced soil bunds have been reported in this paper for protection of transport corridors. There are other reinforced soil bund structures constructed over the last eight years, particularly in Christchurch, for residential protection and other locations in Kaikoura. 


\section{References}

Brunet, G, Giacchetti, G, Bertolo, P \& Peila, D 2009, 'Protection from high energy rockfall impacts using Terramesh embankments: design and experiences', Proceedings of the 60th Highway Geology Symposium, Highway Geology Symposium, pp. 107-124.

Colgan, T \& Ewe, E 2019, 'Design of a large scale rockfall protection bund for coastal transport corridor recovery following the 2016 Kaikoura earthquake', Proceedings of 2019 Pacific Conference on Earthquake Engineering, New Zealand Society for Earthquake Engineering, Wellington, paper 221.

European Organisation for Technical Approvals 2013, Guideline for European Technical Approval of Falling Rock Protection Kits (ETAG 27), European Organisation for Technical Approvals, Brussels.

Ewe, E 2016, 'Reinforced soil structures used in mitigating dynamic rockfall and debris flow impact applications - New Zealand examples', NZ Geomechanics News, issue 97.

Grimod, A \& Giacchetti, G 2011, 'Protection from high energy impacts using reinforced soil embankments: design and experiences', Proceedings of the Second World Landslides Forum.

Lambert, S \& Bourrier, F 2013, 'Design of rockfall protection embankments: a review', Engineering Geology, vol. 154, pp. 77-88.

Ministry of Business, Innovation \& Employment 2016, Rockfall: Design Considerations for Passive Protection Structures, Wellington.

Peila, D 2013, Design of Embankments for Rockfall Protection, presentation notes, International Rockfall Technical Workshop.

Ronco, C, Oggeri, C \& Peila, D 2009, 'Design of reinforced ground embankments used for rockfall protection', Natural Hazards and Earth System Sciences, vol. 9, 1189-1199. 
